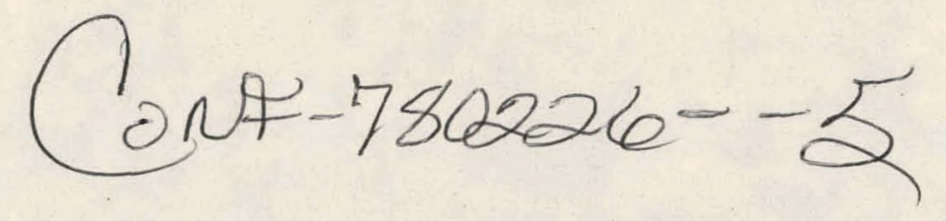

PYRIMIDINE DIMER EXCISION IN EXONUCLEASE DEFICIENT MUTANTS

OF ESCHERICHIA COLI ${ }^{1}$

Warren E. Masker and John W. Chase

Biology Division, Oak Ridge National Laboratory,

Oak Ridge, Tennessee 37830 and Dept. of Molecular Biology,

Albert Einstein College of Medicine, Bronx, New York 10461

$$
9506870
$$

By acceptance of this article, the publisher or recipient acknowledges the U.S. Government's right to retain a nonexclusive, royalty-free license in and to any copyright covering the article.

This report was prepared as an account of work
sponsored by the United States Government. Neither the
Inited States nor the United States Department of
Energy, nor any of their employees, nor any of their
contractors, subcontractors, or their employees, makes
any warranty, express or implied, or assumes any legal
liability or responsibility for the accuracy, completeness
or usefuiness of any information, apparatus, product or
process disclosed, or reptesents that its use would not
infringe privately owned rights.

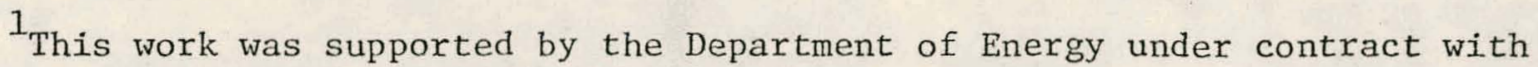
the Union Carbide Corporation, by Public Health Service Grant GI 11301-15 from the National Institute of General Medical Sciences, and by an American Cancer Society Research Grant NP-219. 


\section{DISCLAIMER}

This report was prepared as an account of work sponsored by an agency of the United States Government. Neither the United States Government nor any agency Thereof, nor any of their employees, makes any warranty, express or implied, or assumes any legal liability or responsibility for the accuracy, completeness, or usefulness of any information, apparatus, product, or process disclosed, or represents that its use would not infringe privately owned rights. Reference herein to any specific commercial product, process, or service by trade name, trademark, manufacturer, or otherwise does not necessarily constitute or imply its endorsement, recommendation, or favoring by the United States Government or any agency thereof. The views and opinions of authors expressed herein do not necessarily state or reflect those of the United States Government or any agency thereof. 


\section{DISCLAIMER}

Portions of this document may be illegible in electronic image products. Images are produced from the best available original document. 


\title{
PYRIMIDINE DIMER EXCISION IN EXONUCLEASE DEFICIENT MUTANTS OF ESCHERICHIA COLI.
}

Warxen E. Masker and John W. Chase.

Biology Division, Oak Ridge National Laboratory, Oak Ridge, Tennessee 37830 and Dept. of Molecular Biology, Albert Einstein College of Medicine, Bronx, New York 10461

\begin{abstract}
The rate of pyrimidine dimer excision has been measured in Escherichia coli strains deficient in exonuclease $V$, exonuclease VII, and the $5^{\prime} \rightarrow 3^{\prime}$ exonuclease of DNA polymerase $I$. The results suggest that a reduced level of the $5^{\prime} \rightarrow 3^{\prime}$ exonuclease of DNA polymerase I diminishes the rate of dimer excision and that an additional deficiency in exonuclease VII causes a significantly greater reduction in the cell's ability to remove dimers.
\end{abstract}

\section{INTRODUCTION}

Three $5^{\prime \rightarrow} \rightarrow 3^{\prime}$ exonucleases are currently known in Escherichia coli which may be capable of removing pyrimidine dimers in the excision repair process since they have been shown to excise pyrimidine dimexs in vitro $(1,2,3)$. These are the $5^{\prime} \rightarrow 3^{\prime}$ exonuclease activities associated with DNA polymerases $I$ and III and exonuclease VII. We have extended our previous studies (4) on the exonucleases of $E$. coli involved in excision repair by examining the effect of combined mutations in $r e c B, C, x s e A$, and polAex (deficient in exonuclease $V$, exonuclease VII, and the $5^{\prime}-r 3^{\prime}$ exonuclease activity of DNA polymerase $I$, respectively) $(5,6,7)$ on UV survival and on the rate and extent of dimer excision. Our earlier study (4) demonstrated that mutants deficicnt in exonuclease VII and the $5^{\prime} \rightarrow 3^{\prime}$ exonuclease activity of DNA polymerase I are nearly as efficient as wild-type strains at excising dimers produced by up to $40 \mathrm{~J} / \mathrm{m}^{2} \mathrm{UV}$. At higher doses strains containing only the polA546ex mutation and the polA546ex xseA7 mutations show reduced ability to excise dimers; however, the interpretation of dimer excision data at these doses is complicated by extreme postirradiation DNA degradation in these strains. We

$1_{\text {This work was supported by the Department of Energy }}$ under contract with the Union Carbide Corporation, by Public Health Service Grant GM 11301-15 from the National Institute of General Medical Sciences, and by an American Cancer Society Research Grant NP-219. 
have attempted to reduce postirradiation DNA degradation by reducing the level of exonuclease $\mathrm{V}$ (the recB, $C$ gene product) in order to evaluate the apparent deficiency in dimer excision at high UV doses observed in the polA546ex single mutant and the polA546ex xseA7 double mutant strains. Although there is evidence against the direct involvement of exonuclease $\mathrm{V}$ in the excision repair process. (8), the enzyme might play a more important role in dimer excision when other exonucleases are missing. This fact should be borne in mind in the interpretation of the data presented here.

\section{RESULTS}

We were unable to construct the recB21 derivative of strains containing the polA $546 e x$ mutation suggesting that this may be an inviable combination. Derivatives of these strains were therefore constructed containing the recB270 recC271 temperature-sensitive mutations. (5). As expected, these strains were found to be conditionally lethal. Strains containing only the recB270 recC271 xseA7 mutations show slightly reduced survival at temperatures restrictive to derivatives containing polA546ex.

DNA degradation studies performed after low doses of UV reveal no significant differences between the wild-type and mutant strains after doses of $20 \mathrm{~J} / \mathrm{m}^{2}$. After higher UV doses $\left(90 \mathrm{~J} / \mathrm{m}^{2}\right)$ which caused 50-80\% DNA degradation after $60 \mathrm{~min}$ of $43^{\circ} \mathrm{C}$ incubation in polA546ex and polA546ex $x$ seA7 strains, the recB270 recC271 derivatives of these strains show only about $20 \%$ DNA degradation. DNA degradation in the recB270 recC271 xseA7 strain was indistinguishable from wild-type at all UV . doses. It is therefore possible to reduce postirradiation DNA degradation in these polA546ex derivatives by reducing the levels of exonuclease $V$. UV survival studies show that the recB270 recC271 derivatives of strains containing the polA $546 \mathrm{ex}$ and polA546ex xseA7 mutations are considerably more sensitive to UV irxadiation than any of the strains from which they were constructed. The strain containing the mutations recB270 recC271 xseA7 is only slightly more UV sensitive than strains containing the recB270 recC271 mutation alone (data not shown).

Thymine dimer excision studies were performed on $\mathrm{KLCl} 24$ (wild-type), KLC333 (recB270 recC271 polA546ex), and KLC34I. (recB270 recC271. polA546ex $x$ seA7). Cultures labeled with [ ${ }^{3} \mathrm{H}$ ]-thymine were irradiated, warmed to $43^{\circ} \mathrm{C}$, and samples were examined for thymine-containing dimers as a function of incubation time (Fig. 1). Our results thus far show that KLC333 (recB270 recC271 polA546ex) is slightly reduced in its ability to remove thymine dimers compared to the wild-type. This may mean that the apparent deficiency in dimer excision in the 


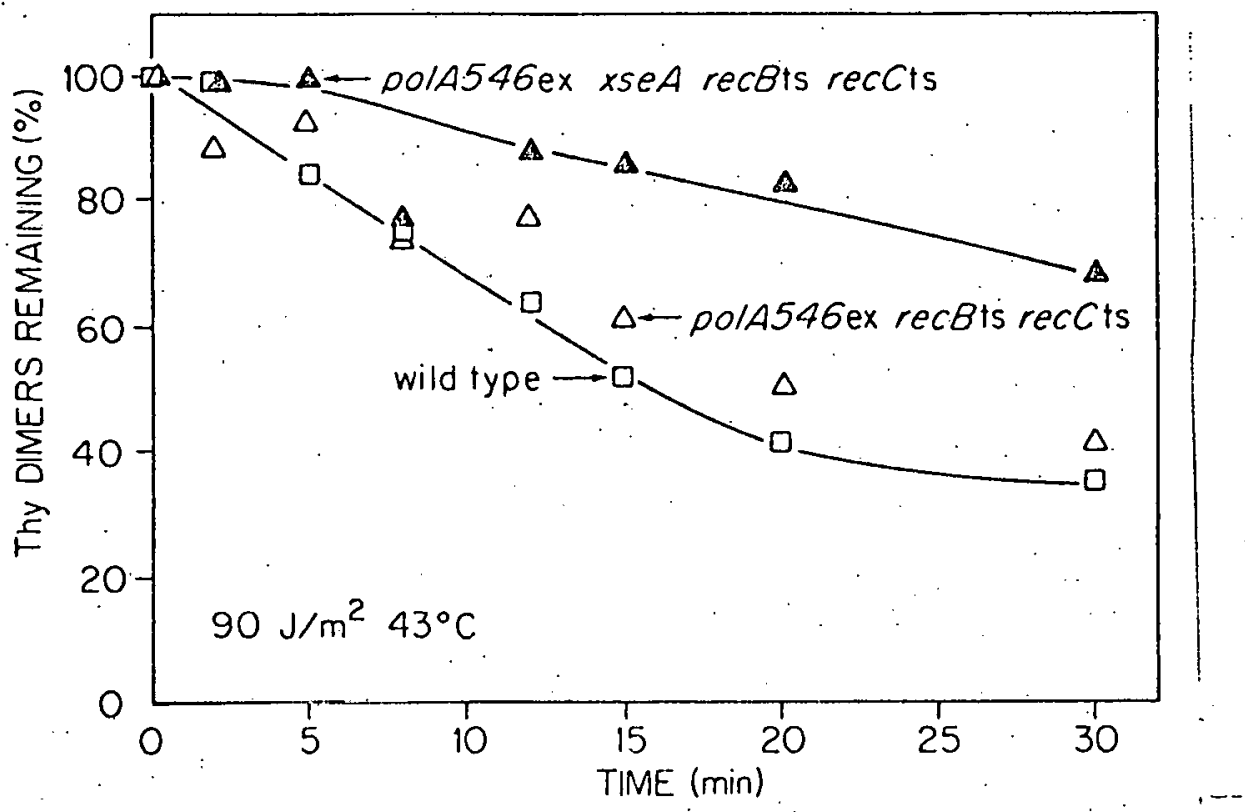

FIGURE 1. Rate of Dimer Excision in Exonuclease Deficient Mutants. Cultures of $E$. coli strains KLCl24: trpA33 rha thyA; KLC333: polA546ex recB270 recC271 trpA33 thyA; and KLC341: polA546ex recB270 recC271 xseA7 trpA33 thyA were grown at $32^{\circ} \mathrm{C}$ to mid-log phase in $M 9$ medium supplemented with

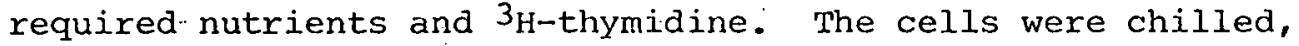
harvested, and washed with M9 salts (without glucose or other additives) before irradiation with $90 \mathrm{~J} / \mathrm{m}^{2} \mathrm{UV}$ light. The cells were warmed to $43^{\circ} \mathrm{C}$ for $5 \mathrm{~min}$, nutrients were added (at $t=0$ ) and samples were withdrawn at the indicated times. The cells were immediately chilled and ice cold NET buffer ( $0.1 \mathrm{M}$ Tris. $\mathrm{HCl}, \mathrm{pH} 8,0.01 \mathrm{M}$ EDTA, $0.1 \mathrm{M} \mathrm{NaCl}$ ) was added. The samples were collected by centrifugation, frozen, thawed and lysed by incubation with $400 \mathrm{\mu g} / \mathrm{ml}$ lysozyme for $30 \mathrm{~min}$ at $43^{\circ} \mathrm{C}$ and $0.2 \%$ sarkosyl for $10 \mathrm{~min}$ at $43^{\circ} \mathrm{C}$. After $30 \mathrm{~min}$ of digestion with $250 \mathrm{\mu g} / \mathrm{ml}$ protease $\mathrm{K}$ at $50^{\circ} \mathrm{C}$, the samples were chilled, TCA was added and the acid insoluble fraction digested with formic acid. Content of thymine dimers was determined by two-dimensional paper chromatography (9). At zero time $0.29 \%$ of the thymine was found as dimers. $\quad \square=\mathrm{KLCl} 24$; $\Delta=\mathrm{KLC} 333 ; \Delta \mathrm{KLC} 341$.

polA546ex single mutant shown in our previous study (4) was largely due to postirradiation DNA degradation. Strain KLC341, however, is significantly deficient in dimer excision compared to wild-type and KLC333, suggesting that the additional deficiency in exonuclease VII in KLC34I is responsible 
for a major reduction in the ability of this strain to excise pyrimidine dimers. A more exhaustive study (to be published) of the extent of dimer excision in this series of mutants over the dose range 0 to $160 \mathrm{~J} / \mathrm{m}^{2}$ confirmed our finding that although the recB270 recC271 polAex strain shows some deficiency in dimer excision, the additional mutation $x s e A$ causes a significant further reduction in the cell's ability to cope with dimers.

\section{DISCUSSION}

We have investigated in some detail the role of two $5^{\prime} \rightarrow 3^{\prime}$ exonuclease activities (exonuclease VII and $5^{\prime} \rightarrow 3^{\prime}$ exonuclease of DNA polymerase I) thought to be involved in excision repair. Compared to wild-type strains, mutants deficient in only one of these activities show either no deficiency or slight deficiency in removing pyrimidine dimers when postirradiation DNA degradation is minimal; strains deficient in both activities show significantly less ability to excise pyrimidine dimers. These results are consistent with the interpretation that both of these enzymes function in the excision process and are able to substitute for one another. Although excision is reduced in strains deficient in both exonuclease VII and the $5^{\prime} \rightarrow 3^{\prime}$ exonuclease of DNA polymerase $I$, it still occurs at a measurable rate. This may be due to residual enzyme levels of either or both of these activities or to other nucleases capable of dimer excision: The only other exonuclease activity of $E$. coli known to be capable of pyrimidine dimer excision in vitro, the $5^{\prime} \rightarrow 3^{\prime}$ exonuclease of DNA polymerase III, has not yet been evaluated in vivo. The possibility also exists that as yet unidentified nucleases participate in the excision step.

\section{REFERENCES}

1. Kelly, R. B., Atkinson, M., Huberman, J., and Kornberg, A. (1969). Nature 244, 495.

2. Chase, J. W., and Richardson, C. C. (1974). J. Biol.. Chem. $249,4553$.

3. Livingston, D: M., and Richardson, C. C. (1975): J. Biol. Chem. 250, 470.

4. Chase, J. W., and Masker, W. E. (1977). J. Bacteriol. 130, 667.

5. Tomizawa, J., and Ogawa, H. (1972). Nature N. Biol. 239, 14 .

6. Konrad, E. B., and Lehman, I. R. (1974). Proc. Nat. Acad. Sci. U.S.A. 71, 2048.

7. Chase, J. W., and Richardson, C. C. (1977) . J. Bacteriol. $129,934$. 
8. Shlaes, D. M., Anderson, J. A., and Barbour, S. D. (1972). J. Bacteriol. 111, 723.

9. Carrier, W. L., and Setlow, R. B. (1971). In "Methods in Enzymology," Vol. 21 (L. Grossman and K. Moldave, eds.), pp. 230-237. Academic Press, New York. 
